\title{
Influence of Pseudomonas fluorescens mutants produced by transposon mutagenesis on in vitro and in vivo biocontrol and plant growth promotion
}

\author{
Abdullah S. Alsohim
}

\begin{abstract}
The fitness of microbes and their colonization efficiency in plants is significant for promotion of plant growth, but the mechanism between plants and bacteria in rhizospheric region is not clearly explained. This study focused on identification and characterization of some plant growth promoting biocontrol bacteria. A total of 94 bacteria strains were isolated and tested for different plant growth promotion activities and their antagonistic behaviors towards different pathogenic fungi. The isolated bacteria were categorized into 23 bacterial genera, using 16S rRNA. The most predominant genera of bacterial isolates were Pseudomonas (4 species) and Bacillus (6 species). The isolates (Qassim University Saudi Arabia (QUSA) 52 and 45) and their transposon mutagenesis mutants inhibited mycelium growth of Rhizoctonia solani, Alternria sp., and Colletotrichum sp. Isolates 52 and 45 of $P$. fluorescens and their mutants' 52-M12, 45-M19, and 45-M20 yielded the highest dry weight and shoot, and root length in alfalfa plants. Furthermore, the efficiency of these bacterial isolates and mutants against $R$. solani was considerably higher than the control treatment.

Therefore, application of biocontrol agents can significantly control the soil-born fungal pathogen in alfalfa plants.
\end{abstract}

Keywords: Plant growth-promoting rhizobacteria, Pseudomonas sp., Bacillus, Mutagenesis, Bio-control, Alfalfa

\section{Background}

Numerous biocontrol bacterial species are still unknown and the knowledge of their antagonism against pathogenic fungi is still poor. Thus, the accurate and reliable identification of biocontrol bacteria is an important task for many, if not all disciplines within microbiology (Busse et al. 1996). Traditionally, biocontrol bacterial isolates were identified and classified based on phenotypic methods according to morphological, physiological, and metabolic markers (Rosselló-Mora and Amann 2001). There are major drawbacks to these phenotypic approaches. They are time-consuming, tedious, and the variability among strains belonging to the same species

Correspondence: a.alsohim@qu.edu.sa; alsohim@hotmail.com Plant Production and Protection Department, College of Agriculture and Veterinary Medicine, Qassim University, Buraydah, Saudi Arabia can be worth (Busse et al. 1996; Mignard and Flandrois 2006). The diversity of rhizobia isolated from Phaseolus vulgaris has been examined worldwide, using a variety of techniques and criteria, where beans originated (Central and South America) and where it was introduced (Koskey et al. 2018). The PCR-RFLP analysis of the 16S-23S rDNA intergenic transcribed spacer (ITS) has proven to be a useful tool for studying the genetic diversity of rhizobia belonging to different genera (Vessey and Cheminigwa 2006, and Lin et al. 2007).

Sequencing of the 16S rRNA gene is a genotypic method by which bacteria can be classified and identified. In literature, there are various reasons that $16 \mathrm{~S}$ rRNA is the most commonly used genetic marker for bacterial identification and classification (Janda and Abbott 2007). These reasons are (1) its function has not
Springer Open
(0) The Author(s). 2020 Open Access This article is licensed under a Creative Commons Attribution 4.0 International License, which permits use, sharing, adaptation, distribution and reproduction in any medium or format, as long as you give appropriate credit to the original author(s) and the source, provide a link to the Creative Commons licence, and indicate if changes were made. The images or other third party material in this article are included in the article's Creative Commons licence, unless indicated otherwise in a credit line to the material. If material is not included in the article's Creative Commons licence and your intended use is not permitted by statutory regulation or exceeds the permitted use, you will need to obtain permission directly from the copyright holder. To view a copy of this licence, visit http://creativecommons.org/licenses/by/4.0/. 
changed over time, (2) the 16S rRNA gene is universal in bacteria, and (3) it is large enough for informatics purposes. Therefore, the advantage of using 16S rRNA over phenotypic approach was reported because it does not require optimal growth conditions and/or cultivation of microorganisms. The 16S rRNA gene sequence has been used to identify various types of slow- and fastgrowth bacteria and rare as well as novel species of

Table 1 Sources and locations of bacterial isolates were collected from Qassim region in Saudi Arabia/QUSA

\begin{tabular}{|c|c|c|}
\hline QUSA & Sample & Source \\
\hline$\overline{1}$ & Soil & Saxaul/Ghada tree (Haloxylonpersicum) - Rawdat Al-Tanhat \\
\hline 2 & Soil & Arta shrub (Calligonumcomosum) - Rawdat Al-Tanhat \\
\hline $3,4,20$ & Root & \\
\hline 21 & Leaves & \\
\hline $5-7$ & Soil & Carrot - Qassim University farm \\
\hline 8,22 & Leaves & Damas tree (Conocarpus) - Qassim University \\
\hline $9-12$ & Leaves & Albizia lebbeck tree - Qassim University \\
\hline 13-15 & Leaves & Palm tree/Phoenix dactylifera - Al-Rajhi palm orchards, Buraidah \\
\hline $16-19$ & Leaves & Ivy/Convolvulus - Al-Rajhi palm orchards, Buraidah \\
\hline $23-27$ & Soil & Barley - Rawdat Al-Tanhat \\
\hline 28 & Roots & \\
\hline 29,30 & Soil & Chenopodiaceae grass - Rawdat Al-Tanhat \\
\hline 31,32 & Roots & \\
\hline $33-34$ & Leaves & Rhazya stricta/Al-Harmal - Rawdat Al-Tanhat \\
\hline 35 & Soil & \\
\hline 36 & Leaves & Plantago ovate/Al-Riblaa - Rawdat Al-Tanhat \\
\hline $37-39$ & Roots & \\
\hline 40 & Soil & \\
\hline $41-43$ & Roots & Launaea (Al-Bakraa) - Rawdat Al-Tanhat \\
\hline $44-50$ & Soil & Clover - Buraidah \\
\hline 51,52 & Roots & \\
\hline 53 & Roots & Wheat - Buraidah \\
\hline 54 & Leaves & Undefined grass 1 - Buraidah \\
\hline $55-58$ & Roots & \\
\hline $59-65,80$ & Soil & \\
\hline 66 & Roots & Pulicaria crispa/Arfag - Buraidah \\
\hline $67-69$ & Roots & Heliotropium bacciferum - Buraidah \\
\hline 70,71 & Soil & \\
\hline 72 & Leaves & \\
\hline 73,74 & Leaves & Astragalus spinosus/Al-Katad - Buraidah \\
\hline 75,77 & Soil & \\
\hline 76,78 & Roots & \\
\hline 79 & Soil & Pulicaria crispa - Buraidah \\
\hline 81 & Soil & Clover - Almulaida, Buraidah \\
\hline 82 & Soil & Arta tree - Almulaida, Buraidah \\
\hline $83-84,94$ & Roots & Undefined grass 2 - Buraidah \\
\hline 85 & Soil & \\
\hline $86-87$ & Leaves & Undefined grass 3 - Buraidah \\
\hline $88,89,90$ & Soil & \\
\hline $91-93$ & Roots & Undefined grass 4 - Buraidah \\
\hline
\end{tabular}


bacteria (Alsohim et al. 2014 and Mignard and Flandrois 2006).

In Saudi Arabia, commercialization of microbial biofertilizers and biocontrol agents are still in its early stage, which no local plant growth promoting rhizobacteria (PGPR) are available in the market (Alsohim et al. 2018). To the best of our knowledge, no study has been performed to develop effective local microbial strains. Thus, the most microbial bio-fertilizers and biocontrol agents in the market are imported from other countries. It has been shown that the survivability of PGPR isolated from a temperate climate rapidly decreases when added to arid soil (Bhattacharjee et al. 2008). Isolation of native strains adapted to the arid environment may contribute to the formulation of inoculants suitable for use with local regional crops. Native isolates may be preferred in the selection of bacteria for inoculation, as they are adapted to the environment and thus can be more competent than imported biocontrol bacteria (Karagöz et al. 2012). Using natural soil isolates inoculated into the plant rhizosphere has the advantage of being the easiest way for adaptation and succession (Chen et al. 2006). Pseudomonas bacteria are used as model organisms in these colonization studies because they are among the important bacteria existing in the rhizosphere (Lugtenberg et al. 2001). For example, Lugtenberg et al. (2001) conducted a systematic search for mutants affected in competitive root colonization with $P$. fluorescens WCS365. This was done via transposon (Tn5) mutagenesis, and they generated a bank of mutants that were used to test their ability of in competitive fitness. It also has been reported that bacteria (Pseudomonas fluorescens) colonized the base of the root in higher densities than in other parts of the root and that they decreased by twofold towards the top of root (Simons et al. 1996 and Chin-A-Woeng et al. 1997). The Qassim region, Saudi Arabia, is located in an arid zone characterized by low rainfall, extreme temperatures, and infertile with salt-affected soils. However, agricultural activities in Qassim are known to depend on groundwater and the use of chemical fertilizers to enhance soil fertility and crop productivity. The excessive use of chemical fertilizers often results in unexpected harmful environmental effects, including accumulation of nitrate in plant tissues, leaching of nitrate into groundwater and surface runoff of phosphorus and nitrogen. Obviously, an integrated nutrient management system is required to maintain agricultural productivity and protect the environment.

Therefore, microbial inoculants are promising components for integrated solutions to agro-environmental problems (Alsohim 2015), which deduced that PGPR isolates (Sinorhizobium sp.) may have the potential to act as PGPR that can enhance plant growth, particularly under stressed environmental conditions. It is, therefore, necessary to develop effective biofertilizers containing native PGPR strains that can adapt well to the arid environment. Rhizosphere of perennial plants, which are well adapted to the local environment are perhaps the best source of native microbial isolates (Hanna et al. 2012).

Therefore, the objectives of this study were to (1) isolate and purify biocontrol bacteria from a range of plant species, (2) use mutagenesis to identify mutants that promote the plant growth, in vitro evaluation of bacteria and mutants for suppression of oomycete and fungal growth together, and (3) characterize the selected bacteria by genome sequencing and conduct in vivo test with those bacteria mutants for plant growth promotion with and without fungal pathogens.

\section{Material and methods \\ Isolation of bacteria strains}

Bacterial isolates were obtained from plant samples of various trees, bushes, and desert grasses growing at different sites in the Al-Qassim region, Saudi Arabia (Alsohim 2015) (Table 1). The plant samples contained some parts of soil, roots, and leaves, were carefully collected in plastic bags, and then stored at $4{ }^{\circ} \mathrm{C}$ until used.

After removing adhering soil, the plant root samples were cut into small pieces and crushed in sterile water. The plant leaves were also crushed in sterile water. As well as, $10 \mathrm{~g}$ of the soil from each of the rhizosphere samples was transferred to $100 \mathrm{ml}$ of sterile water. These 3 suspensions were serially diluted, and $100 \mu$ of each 10-4, 10-5, and 10-6 homogenized dilutions was distributed into nutrient agar (NA) medium. Plates were

Table 2 Plant pathogenic fungi tested in the fungal inhibition growth assay and their sources

\begin{tabular}{lll}
\hline No. & Fungi & Source \\
\hline 1 & Fusarium moniliform & Drought on palm tree - pathology lab \\
2 & Fusarium solani & Biotechnology lab \\
3 & Fusarium oxysporum & Biotechnology lab \\
4 & Fusarium graminiarum & Pathology lab \\
5 & Fusarium oxysporum.c. & Pathology lab \\
6 & Fusarium sp. (purple) & Pathology lab \\
7 & Fusarium sp. (white) & Isolated from tomato - pathology lab \\
12 & Fusarium sp. (white1) & Palm tree - pathology lab \\
8 & Fusarium sp. (pink) & Biotechnology lab \\
9 & Rhizoctonia solani & Biotechnology lab \\
10 & Colletotrichum sp. & Al-Rajhi horticulture - pathology lab \\
11 & Botrytis sp. & Strawberry fruit \\
13 & Alternaria sp. & Leaf spot on palm tree - pathology lab \\
14 & Stemphylium sp. & Pathology lab \\
\hline
\end{tabular}


Table 3 Identification of bacterial isolates (QUSA) and their high similarity using 165 rDNA gene sequencing

\begin{tabular}{|c|c|c|}
\hline QUSA & Description & Identity \\
\hline 2 & Bacillus sp. PVR-YHB-4-1 & $97 \%$ \\
\hline 5 & Klebsiella sp. IPPW-15 & $93 \%$ \\
\hline 7 & Chryseobacterium sp. K-2 & $99 \%$ \\
\hline 10 & Acinetobacter sp. NC95 partial & $99 \%$ \\
\hline 11 & Bacillus licheniformis strain MK7 & $98 \%$ \\
\hline 14 & Uncultured Acinetobacter sp. clone GI3-S-1-G03 & $99 \%$ \\
\hline 16 & Psychrobacter sp. MVS1-N6 & $98 \%$ \\
\hline 17 & Pseudomonas sp. CB14 & $88 \%$ \\
\hline 19 & Paracoccus sp. B22 & $98 \%$ \\
\hline 23 & Microbacterium sp. AHW1G3 & $92 \%$ \\
\hline 25 & Pseudomonas stutzeri strain L1 & $99 \%$ \\
\hline 26 & Pantoea dispersa strain p91_G09 & $98 \%$ \\
\hline 27 & Uncultured Pseudomonas sp. clone CV-3 & $93 \%$ \\
\hline 28 & Stenotrophomonas maltophilia strain Ysm & $82 \%$ \\
\hline 29 & Lysinibacillus fusiformis strain B-13 & $93 \%$ \\
\hline 30 & Enterobacter sp. FCB1 & $98 \%$ \\
\hline 31 & Pseudomonas sp. NR 6-02 & $89 \%$ \\
\hline 32 & Pseudomonas syringae strain 8532 & $98 \%$ \\
\hline 33 & Achromobacter sp. GMCo22 & $86 \%$ \\
\hline 34 & Pantoea sp. LP10_RH04 & $99 \%$ \\
\hline 35 & Stenotrophomonas sp. SMAKK001 & $85 \%$ \\
\hline 36 & Bacillus subtilis strain PSM5 & $85 \%$ \\
\hline 37 & Bacillus sp. RC2 partial & $86 \%$ \\
\hline 40 & Arthrobacter nicotianae strain Lb-41 & $91 \%$ \\
\hline 41 & Pseudomonas sp. AD3.12 & $99 \%$ \\
\hline 42 & Cronobacter dublinensis strain PYJ131 & $97 \%$ \\
\hline 43 & Pseudomonas sp. TK37 & $98 \%$ \\
\hline 44 & Pseudomonas sp. PS-4 & $98 \%$ \\
\hline 45 & Pseudomonas sp. PS-4 & $99 \%$ \\
\hline 46 & Pseudomonas stutzeri strain NM2E7 & $98 \%$ \\
\hline 47 & Exiguobacterium sibiricum strain IHB B 14506 & $97 \%$ \\
\hline 48 & Pseudomonas stutzeri strain S16(B)12 BRNEIST-DST & $88 \%$ \\
\hline 49 & Bacillus sp. T3-33 & $99 \%$ \\
\hline 51 & Pseudomonas amygdali pv. tabaci strain YWTG-1 & $99 \%$ \\
\hline 52 & Pseudomonas fluorescens Pf0-1, complete genome & $98 \%$ \\
\hline 53 & Bacillus sp. TAE13 gene & $99 \%$ \\
\hline 57 & Rhodospirillum sp. kmd_187 & $97 \%$ \\
\hline 58 & Pseudomonas sp. TK37 & $99 \%$ \\
\hline 60 & Bacillus flexus strain p8_B09 & $84 \%$ \\
\hline 61 & Bacillus sp. 2BSG-MG-25 gene & $99 \%$ \\
\hline 62 & Bacillus sp. RSP-VIW-56 & $99 \%$ \\
\hline 63 & Pseudomonas sp. CP07 & $89 \%$ \\
\hline 64 & Pseudomonas sp. B3053 & $88 \%$ \\
\hline
\end{tabular}

Table 3 Identification of bacterial isolates (QUSA) and their high similarity using $16 \mathrm{~S}$ rDNA gene sequencing (Continued)

\begin{tabular}{lll}
\hline QUSA & Description & Identity \\
\hline 65 & Planomicrobium sp. PLB025 & $97 \%$ \\
66 & Pseudomonas sp.H-128 strain H-128 & $94 \%$ \\
67 & Enterobacter aerogenes strain DD2 & $93 \%$ \\
72 & Bacillus firmus strain IARI-IR1 & $97 \%$ \\
74 & Bacillus licheniformis strain SCK 121053 & $96 \%$ \\
77 & Mesorhizobium sp. UASWS1017 & $98 \%$ \\
80 & Planococcus sp. R-4-H-7 & $96 \%$ \\
86 & Bacillus atrophaeus strain UAsDu82 & $96 \%$ \\
87 & Bacillus pumilus strain K22 & $99 \%$ \\
90 & Salinicoccus hispanicus strain JM-T11 & $99 \%$ \\
91 & Erwinia sp. GY35 16S ribosomal RNA gene & $99 \%$ \\
92 & Planomicrobium sp. PLB025 & $99 \%$ \\
\hline
\end{tabular}

incubated at $28 \pm 1{ }^{\circ} \mathrm{C}$ (Alsohim et al. 2018) for isolation of bacteria.

\section{Identification of PGPR isolates through DNA sequencing}

Rhizobacterial isolates, that grown overnight in nutrient broth and genomic DNA, were extracted by the hexadecyltrimethy-l ammonium bromide (CTAB) method (Doyle and Doyle 1990). The bacterial 16S rDNA primer Ps-for (5'GGTCTGAGAGGATGATCAGT3') and Ps-rev (5'TTAGCTCCACCTCGCGGG3') were used to amplify the $16 \mathrm{~S}$ rDNA gene region. Polymerase chain reaction (PCR) was using a DNA Engine DYAD $^{\mathrm{m}}$ Peltier Thermal Cycler. Thermal cycling was performed by carrying out initial denaturation at $94^{\circ} \mathrm{C}$ for $5 \mathrm{~min}$, followed by 30 cycles at $94{ }^{\circ} \mathrm{C}$ for $1 \mathrm{~min}, 55^{\circ} \mathrm{C}$ for $1 \mathrm{~min}, 72^{\circ} \mathrm{C}$ for $1.5 \mathrm{~min}$, and the final extension at $72{ }^{\circ} \mathrm{C}$ for $8 \mathrm{~min}$. The fragments obtained were analyzed via gel electrophoresis $(24 \times 12 \mathrm{~cm})$ with $2 \%$ agarose, and carried out at $80 \mathrm{~V}$ for $2 \mathrm{~h}$. A $1 \mathrm{~kb}$ DNA ladder load on the left lane of the gel was used as a molecular size marker. The PCR products were sent to the Macrogen Company in Korea for sequencing. The sequence search for the alignment of nucleotides was performed using the BLAST (basic local alignment search tool) webbased program.

\section{Fungal inhibition growth assay}

The bacterial isolates were tested for their ability to inhibit the growth of some important fungal plant pathogens. Four genera (Fusarium, Rhizoctonia solani, Colletotrichum sp., and Botrytis sp.) were tested in this assay. Fungal isolates information are described in Table 2. Four single-bacterial colonies of the bacterial isolates ( $P$. fluorescens) were streaked on four edges of PDA containing Petri dishes and one disk of a new colony of the tested fungi was placed in the 
Table 4 Reaction of mutants of bacterial isolate no. 52 (Pseudomonas fluorescens) tested for their antagonism to Rhizoctonia solani and Colletotrichum sp.

\begin{tabular}{|c|c|c|c|c|c|}
\hline Mutant no. & Rhizoctonia solani after 1 day & R. solani after 5 days & Colletotrichum after 1 day & Colletotrichum after 5 days & Fluorescent \\
\hline Iso. 52 & +++ & +++ & ++ & ++ & + \\
\hline 1 & +++ & - & - & - & - \\
\hline 2 & +++ & +++ & +++ & +++ & + \\
\hline 3 & +++ & +++ & +++ & +++ & + \\
\hline 4 & +++ & +++ & +++ & +++ & + \\
\hline 5 & + & - & + & + & - \\
\hline 6 & - & - & +++ & + & - \\
\hline 7 & - & - & - & - & - \\
\hline 8 & +++ & +++ & +++ & +++ & - \\
\hline 9 & + & +++ & +++ & +++ & - \\
\hline 10 & - & - & - & - & - \\
\hline 11 & +++ & +++ & +++ & +++ & + \\
\hline 12 & + & - & - & - & - \\
\hline 13 & +++ & +++ & +++ & +++ & + \\
\hline 14 & +++ & +++ & +++ & +++ & + \\
\hline 15 & + & - & - & - & - \\
\hline 16 & + & - & + & + & - \\
\hline 17 & +++ & +++ & +++ & +++ & + \\
\hline 18 & + & - & - & - & - \\
\hline 19 & +++ & +++ & +++ & +++ & + \\
\hline 20 & + & - & - & - & - \\
\hline 21 & + & - & - & - & - \\
\hline 22 & ++++ & ++++ & ++++ & ++++ (wide free area) & + \\
\hline 23 & + & - & + & - & - \\
\hline 24 & ++++ & ++++ & ++++ & ++++ (wide free area) & + \\
\hline 25 & & - & & - & - \\
\hline 26 & & +++ & & +++ & + \\
\hline 27 & & +++ & & +++ & + \\
\hline 28 & & - & & - & - \\
\hline 29 & & +++ & & +++ & + \\
\hline 30 & & - & & + & - \\
\hline 31 & & - & & - & - \\
\hline 32 & & +++ & & +++ & + \\
\hline
\end{tabular}

center of the Petri dish. The plates were incubated at $28{ }^{\circ} \mathrm{C}$ until the fungal mycelium covered the entire control dish after 4 days. The ability of IS- $\Omega-\mathrm{Km} / \mathrm{hah}$ mutants to inhibit the growth of the fungi was tested on PDA plates; all bacterial strains were inoculated as a $5 \mu \mathrm{l}$ droplet from an overnight broth (cell density adjusted to OD $600=0.5$ ) and allowed to grow overnight on a PDA agar plate. Fungi were then inoculated at the center of the PDA agar plates and incubated at $28^{\circ} \mathrm{C}$.
As the bacterial isolates showed antifungal activity, the observed inhibition of fungal mycelium growth was estimated using a three-level scale: $(+)$ fungal mycelium showed delay in growth compared with the control, $(++)$ fungal mycelium stopped growing in contact with the bacterial colony, and $(+++)$ presence of clear antagonistic area free of fungal mycelium surrounding the bacterial colony. The inhibition zone $(\mathrm{mm})$ was recorded by measuring the distance between the edges of the fungal mycelium and the bacterial streak. 
Table 5 Quantitative reaction of mutants of bacterial isolate no. 45 (Pseudomonas sp.) tested for their antagonism against Rhizoctonia solani, Colletotrichum sp., Fusarium solani, F. moniliforme, F. oxysporum, Fusarium sp., and Botrytis sp.

\begin{tabular}{llllllll}
\hline Mutant No. & R. so & F. so & F. mon & F. ox & F. gra & Thial. & Bot. \\
\hline Iso 45 & +++ & - & - & - & - & - & +++ \\
1 & ++ & - & - & - & - & - & + \\
2 & - & - & - & - & - & - & + \\
3 & - & - & - & - & - & - & +++ \\
4 & - & - & - & - & - & - & - \\
5 & - & - & - & - & - & - & ++ \\
6 & - & - & - & - & - & - & - \\
7 & - & - & - & - & - & - & - \\
8 & - & - & - & - & - & - & - \\
9 & - & - & - & - & - & - & +++ \\
10 & - & - & - & - & - & - & ++ \\
11 & - & - & - & - & - & - & +++ \\
12 & - & - & - & - & - & - & + \\
13 & - & - & - & - & - & - & - \\
14 & - & - & - & - & - & - & ++ \\
16 & - & - & - & - & - & - & +++ \\
17 & - & - & - & - & - & - & +++ \\
18 & ++ & - & - & - & - & - & ++ \\
19 & - & - & - & - & - & - & - \\
20 & +++ & - & - & - & - & - & +++ \\
\hline
\end{tabular}

\section{Construction of a Pseudomonas fluorescens transposon mutant using bacterial conjugation}

Bacteria ( $P$. fluorescens) isolates 45 and 52 were grown overnight in Luria broth (LB) at $27^{\circ} \mathrm{C}$ and Escherichia coli was grown overnight in $\mathrm{LB}$ at $37^{\circ} \mathrm{C}$. Next, $900 \mu \mathrm{l}$ of bacteria cells were mixed with $600 \mu \mathrm{l}$ of the S17-11pir carrying plasmid pSCR001 (and $600 \mu \mathrm{l}$ of E. coli strain containing the helper plasmid, DH5 $\alpha$ (pRK2013), if used). The cells were mixed and centrifuged at 13, $000 \mathrm{rpm}$ to obtain a pellet. The mixture was then washed twice with sterile water. The cell suspension was spotted on LB agar plates and incubated overnight at $27^{\circ} \mathrm{C}$. These bacterial mating spots were then recovered and placed in $1 \mathrm{ml}$ of sterile water and diluted 10-1 and 10-2. The suspensions were spread onto LB plates supplemented with antibiotics in order to select the trans-conjugants carrying the plasmid or for transposon mutagenesis. Two hundred isolates of IS- $\Omega-\mathrm{Km} / \mathrm{hah}$ transposon mutants were generated by the conjugation of bacteria with S17-1גpir (pSCR001) and selecting of $\mathrm{Kmr}$ mutants. Mutants were selected and arranged in micro titer dishes in order to produce frozen stocks and create the transposon library (Alsohim et al. 2014).

\section{Testing selected bacteria in vivo for PGPR in the presence} or absence of fungal isolates in greenhouse

In vivo experiments were conducted with biocontrol bacteria to determine whether they could improve plant growth (in the absence of pathogens) and protect plants (in the presence of pathogens). Alfalfa seeds were sterilized by Clorox $1 \%$ for $5 \mathrm{~min}$ and inoculated with selected bacterial isolates prior to exposure to the phytopathogenic fungi. The seeds were soaked for $10 \mathrm{~min}$ in bacterial containing bacterial isolates. The bacterial isolates (isolate 45; Pseudomonas sp., Mutant45-M19, Mutant 45-M20, isolate 52; P. fluorescens Pf0-1, Mutant 52-M12, and Mutant 52-M22) were tested for ability to protect the alfalfa roots against Rhizoctonia solani. The bacterial isolates (isolate 45; Pseudomonas sp., Mutant 45-M19, Mutant 45-M20, isolate 37; Bacillus sp.) were tested against Botrytis sp. The isolates were grown in nutrient broth on a rotary shaker at $30{ }^{\circ} \mathrm{C}$ and $170 \mathrm{rpm}$ for $24 \mathrm{~h}$.

Table 6 Thirty days after inoculation: shoot and root measurements of alfalfa plants under different treatments

\begin{tabular}{llllll}
\hline No. & Treatment & Shoot length $(\mathrm{cm})$ & Root length $(\mathrm{cm})$ & Fresh weight $(\mathrm{mg} /$ plant $)$ & Dry weight $(\mathrm{mg} /$ plant $)$ \\
\hline $\mathbf{1}$ & Isolate $\mathbf{4 5}$ & $14.3 \mathrm{bc}$ ( & $7.7 \mathrm{ba}$ & $1.4 \mathrm{c}$ & $0.6 \mathrm{~b}$ \\
2 & Mutant $\mathbf{4 5 - 1 9}$ & $15.3 \mathrm{~b}$ & $8.0 \mathrm{ba}$ & $1.5 \mathrm{~b}$ & $0.7 \mathrm{ab}$ \\
3 & Mutant $\mathbf{4 5 - 2 0}$ & $16 \mathrm{~b}$ & $8.0 \mathrm{ba}$ & $1.3 \mathrm{~d}$ & $0.6 \mathrm{~b}$ \\
$\mathbf{4}$ & Isolate $\mathbf{3 7}$ & $20.7 \mathrm{a}$ & $8.7 \mathrm{a}$ & $1.6 \mathrm{a}$ & $0.8 \mathrm{a}$ \\
$\mathbf{5}$ & Bot-45 & $16.3 \mathrm{~b}$ & $7.0 \mathrm{ba}$ & $1.3 \mathrm{~cd}$ & $0.7 \mathrm{ab}$ \\
6 & Bot-45-19 & $14.7 \mathrm{~b}$ & $6.3 \mathrm{~b}$ & $0.8 \mathrm{f}$ & $0.4 \mathrm{c}$ \\
7 & Bot-45-20 & $14.3 \mathrm{~b}$ & $6.7 \mathrm{ba}$ & $0.6 \mathrm{~g} \mathrm{c}$ \\
$\mathbf{8}$ & Bot-37 & $16.7 \mathrm{~b}$ & $7.7 \mathrm{ba}$ & $1.6 \mathrm{a}$ & $0.8 \mathrm{a}$ \\
9 & Bot. & $0.0 \mathrm{~d}$ & $0.0 \mathrm{c}$ & $0.0 \mathrm{~h}$ & $0.0 \mathrm{~d}$ \\
10 & Seeds & $10.7 \mathrm{c}$ & $6.0 \mathrm{~b}$ & $0.8 \mathrm{f}$ & $0.4 \mathrm{c}$ \\
\hline
\end{tabular}

Seeds (Control 1) not inoculated with any microbe, Bot. (Control 2) only inoculated with Botrytis sp.

*Significant at the 0.01 probability level 
The isolates were grown on LB broth at $28^{\circ} \mathrm{C}$ for 3 days and further evaluated for their PGP traits. The suspensions were centrifuged in sterile $50-\mathrm{ml}$ falcon tubes at $6000 \mathrm{rpm}$ for $10 \mathrm{~min}$. The pellets were then resuspended in sterile distilled water to obtain a final concentration of 108 cells ml$^{-1},(O D=0.5)$ at $600 \mathrm{~nm}$, which was measured, using the viable plate count and optical density methods (Alsohim et al. 2018).

The soil used in the pot experiment was sterilized to minimize the influence of other microorganisms and airdried prior to the experiment. Plants were monitored in a growth chamber at $30^{\circ} \mathrm{C}$ with a photoperiod of $15 \mathrm{~h}$. The experiments were arranged in a randomized complete block design (RCBD) with three replicates and repeated twice. After 4 weeks from inoculation, characteristics measured included plant root weight and length, plant shoot weight and length, and plant biomass (wet and dry).

\section{Statistical analysis}

The analysis of variance for plant characteristics was computed, using the MSTATC microcomputer program (MSTATC 1990).

\section{Results and discussion PGPR identification}

Isolates, which showed interesting PGPR characteristics, were further identified via sequencing of their $16 \mathrm{~S}$ rDNA gene. The BLAST searches against the NCBI nucleotide database revealed close relationships to known plantassociated bacteria, including the 23 genera as Arthrobacter, Bacillus, Cronobacter, Enterobacter, Erwinia, Klebsiella, Lysinibacillus, Mesorhizobium, Pantoea,
Pseudomonas, Staphylococcus, and Stenotrophomonas (Table 3). The most predominant genera of the bacterial isolates were Pseudomonas (QUSA-17) (4 species) and Bacillus (6 species). These isolates were also found in rhizosphiric soil of Himachal Pradesh, India, as reported by Kumar et al. (2012) and used in a biofertilizer formulation. The BLAST search results through NCBI showed the highest (99\%) similarity index of isolate QUSA-34 with Pantoea sp. The highest sequence resemblance of isolates (QUSA-41 and QUSA-45) with Pseudomonas sp. and Bacillus pumilus for isolate QUSA-87, as described in Table 2. Hayat et al. (2013) identified 9 Gram-positive bacterial strains from legume rhizospheric soil, using $16 \mathrm{~S}$ rRNA gene sequencing. These strains showed the highest similarity (97.9-99.8\%) to the genus Bacillus and were characterized for plant growth promoting (PGP) activities in legume and cereal crops.

\section{Construction of Pseudomonas sp. transposon mutants}

In this study, transposon mutagenesis of Pseudomonas sp. produced mutants that are effective in the protection of alfalfa plants against fungi than the bacterial isolates. Moreover, some mutants of Pseudomonas sp. showed more protection of alfalfa plants in soil infected with plant pathogen such as $R$. solani and Botrytis sp. than in bacterial isolates. Thus, some genes that mutated are useful target for biocontrol of plants growth promotion agents.

\section{In vitro biocontrol assay of mutagenesis mutants}

After $24 \mathrm{~h}$, fungi had spread over the plate towards the bacterial colonies. A clear inhibition zone was observed around mutants 22 and 24 of $P$. fluorescens (isolate 52)

Table 7 Thirty days after inoculation: shoot and root measurements of alfalfa plants under different treatments

\begin{tabular}{|c|c|c|c|c|c|}
\hline No. & Treatment & Shoot length $(\mathrm{cm})$ & Root length $(\mathrm{cm})$ & Fresh weight (mg) & Dry weight (mg) \\
\hline 1 & Isolate 52 & $10.3 c^{*}$ & $5.0 \mathrm{~cd}$ & 0.8 ef & 0.5 ef \\
\hline 2 & Mutant 52-12 & $16.3 \mathrm{a}$ & $8.3 \mathrm{a}$ & $1.6 \mathrm{a}$ & $0.9 \mathrm{a}$ \\
\hline 3 & Mutant 52-22 & $9.0 \mathrm{c}$ & $4.3 \mathrm{~d}$ & 0.9 e & 0.5 ef \\
\hline 4 & Isolate 45 & $14.3 \mathrm{ab}$ & $7.7 \mathrm{a}$ & $1.3 \mathrm{~cd}$ & $0.7 \mathrm{~cd}$ \\
\hline 5 & Mutant 45-19 & $16.7 \mathrm{a}$ & $8.0 \mathrm{a}$ & $1.4 \mathrm{bc}$ & $0.7 b c$ \\
\hline 6 & Mutant $45-20$ & $16.0 \mathrm{a}$ & $8.0 \mathrm{a}$ & $1.3 \mathrm{~d}$ & $0.6 \mathrm{ed}$ \\
\hline 7 & Rh-52 & $12.0 \mathrm{bc}$ & $5.3 \mathrm{bcd}$ & $0.7 \mathrm{~g}$ & $0.4 \mathrm{fg}$ \\
\hline 8 & Rh-52-12 & $17.0 \mathrm{a}$ & $8.3 \mathrm{a}$ & $1.5 \mathrm{ab}$ & $0.8 \mathrm{a}$ \\
\hline 9 & Rh-52-22 & $14.3 \mathrm{ab}$ & $6.0 \mathrm{abcd}$ & $1.5 \mathrm{~b}$ & $0.7 \mathrm{fcd}$ \\
\hline 10 & Rh-45 & $17.3 \mathrm{a}$ & $8.3 \mathrm{a}$ & $1.6 \mathrm{~d}$ & $0.9 \mathrm{ed}$ \\
\hline 11 & Rh-45-19 & $16.0 \mathrm{a}$ & $7.7 \mathrm{a}$ & $1.5 \mathrm{~b}$ & $0.8 a b$ \\
\hline 12 & Rh-45-20 & $15.3 \mathrm{ab}$ & $6.7 \mathrm{abc}$ & $0.8 f$ & $0.4 \mathrm{fg}$ \\
\hline 13 & $\mathrm{Rh}$ & $0.0 \mathrm{~d}$ & $0.0 \mathrm{e}$ & $0.0 \mathrm{~h}$ & $0.0 \mathrm{fh}$ \\
\hline 14 & Seeds & $10.7 \mathrm{C}$ & $6.0 \mathrm{abcd}$ & $0.8 \mathrm{f}$ & $0.3 \mathrm{~g}$ \\
\hline
\end{tabular}

Seeds (Control 1) not inoculated with any microbe; Rh (Control 2) only inoculated with Rhizoctonia solani

*Significant at the 0.01 probability level 
compared with wild type and the other transposon mutants. An absence of mycelium was observed in the inhibition zone around the colonies (Table 4). Moreover, there was no difference between the wild type and mutant 20 of $P$. fluorescens (isolate 45) in fungi inhibition zone (Table 5). This suggested that some mutant's genes played an important role in inhibiting pathogen growth in vitro.

It was previously reported that the plant growth promotion and suppression pathogenic disease caused by Pythium using Pseudomonas strains such as SBW25 and CHAO (Naseby et al. 2001). This study found that $P$. fluorescens and some mutants (isolate 52-mutant \#22 and isolate 45-mutant \#20) had the ability to inhibit the growth of two plant pathogens ( $R$. solani and Botrytis sp.). It was found that the fungal and oomycete growth was also inhibited by $P$. fluorescens and some mutants (isolate 52-mutant \#22 and isolate 45-mutant \#20), but that was not found with the viscosin mutants and thus corroborate with the observation of De Bruijn et al. (2007), i.e., the production of viscosin biosurfactants caused zoospore lysis in the oomycete plant pathogen Phytophthora infestans.

\section{In vivo antagonism of isolates $(37,45$, and 52$)$ and its mutants against $R$. solani and Botrytis sp.}

Shoot and root lengths, and the fresh and dry weight tendency of surviving plants were significantly affected by inoculated bacteria in alfalfa plants grown in the experiments (Tables 6 and 7). The shoot and root lengths of alfalfa plants (Table 6) grown in the soil treated with the isolate Bacillus sp. were significantly higher than (20.7 $\mathrm{cm}$ and $8.7 \mathrm{~cm}$, respectively) with the other treatments. Dissimilarity was observed in fresh and dry weight in soil treated with P. fluorescens against Botrytis sp. Isolates 52 and 45 of $P$. fluorescens along with mutants' 52-M12, 45-M19, and 45-M20 observed with a maximum dry weight and length of shoots and roots of alfalfa plants (Table 7). Furthermore, the efficiency of these bacterial isolates and their mutants against $R$. solani was significantly higher than with the control treatment due to an increase in the dry weight of alfalfa under the infection with $R$. solani. Compared with the application of selected bacterial isolates, obtained findings indicate that application of biocontrol agent could significantly boost the capability to suppress soil-born fungi in alfalfa plants. Additionally, R. solani and Botrytis sp. also significantly reduced the seedling emergence in this study. The effect of Botrytis sp. was partially suppressed by Bacillus sp. (isolate \#37). However, isolate 45 and mutants (M 45-19 and M45-20) of P. fluorescens were found to be less protective against Botrytis sp. Contrarily, isolates 52 and 45 and mutants (52-M12 and 45M19) of $P$. fluorescens were more effective against $R$. solani. While, in root and shoot lengths and weights of alfalfa seedlings, $P$. fluorescens was found most effective against the two pathogens ( $R$. solani and Botrytis sp.). Seeds treated with the mutants (52-M12 and 45-M19) under infection resulted in shoot and root length and weight as seen with the mutants (52-M12 and 45-M19) without infection of $R$. solani. Therefore, this disease might be suppressed by plant growth promoting bacteria (Pseudomonas sp.) by reducing the pathogen populations through production of antimicrobials (Naseby et al. 2001). This study proved that some genes in P. fluorescens distributed by transposon mutagenesis need to be more investigated to identify the location of these genes and their function.

\section{Conclusion}

The results revealed that $P$. fluorescens and mutants (isolate 52-mutant \#22 and isolate 45-mutant \#20) had the ability to inhibit the growth of two plant pathogens. The bacterial isolates and their mutants against $R$. solani and Botrytis sp. were significantly higher than the control. Therefore, the results can suggest that application of biocontrol agents could significantly restrict soil-born fungal pathogens in alfalfa plants.

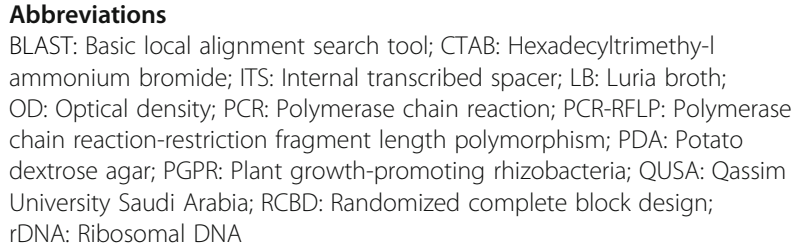
ammonium bromide; ITS: Internal transcribed spacer; LB: Luria broth; OD: Optical density; PCR: Polymerase chain reaction; PCR-RFLP: Polymerase chain reaction-restriction fragment length polymorphism; PDA: Potato dextrose agar; PGPR: Plant growth-promoting rhizobacteria; QUSA: Qassim University Saudi Arabia; RCBD: Randomized complete block design; rDNA: Ribosomal DNA

\section{Acknowledgements}

The author gratefully acknowledges Mr. Taha Abdul Elatif for the molecular analysis. The author thanks Dr. M. I. Motawei for his technical support and help in managing the data. Our appreciation is extended to Prof. H. Mousa for his assistance in reviewing the manuscript and Mrs. Nuriye Peaci for editing the English language in my manuscript.

\section{Authors' contributions}

The author performed most of the experimental work and analyzed the data. The author read and approved the final manuscript.

\section{Funding}

This project was funded by Qassim University, Kingdom of Saudi Arabia.

\section{Availability of data and materials}

The datasets analyzed during the current study are available from the corresponding author on a reasonable request.

\section{Ethics approval}

This study was approved by College of Agriculture and Veteterinary Medicine, Ethics Committee, Qassim University, Saudi Arabia.

\section{Consent for publication}

The author participated in this research article.

Competing interests

The author declares that there are no competing interests. 
Received: 4 December 2019 Accepted: 18 February 2020

Published online: 28 February 2020

\section{References}

Alsohim AS (2015) Molecular and physiological characterization of plant growth promoting rhizobacteria from rhizosphere soil in Al-Qassim, Saudi Arabia. J Food Agric Environ 13(2):118-121

Alsohim AS, Al-Mohamed R, Motawei MI (2018) Isolation, screening and characterization of new PGPR isolates from rhizosphere of alfalfa plants. J Food Agric Environ 16(2):81-85

Alsohim AS, Taylor TB, Barrett GA, Gallie J, Zhang XX, Altamirano-Junqueira AE, Johnson LJ, Rainey PB, Jackson RW (2014) The biosurfactant viscosin produced by Pseudomonas fluorescens SBW25 mediates in vitro spreading motility and plant growth promotion. Environ Microbiol 16(7):2267-2281

Bhattacharjee S, van Ooij C, Balu B, Adams JH, Haldar K (2008) Maurer's clefts of Plasmodium falciparum are secretory organelles that concentrate virulence protein reporters for delivery to the host erythrocyte. Blood 111:2418-2426

Busse HJ, Denner EBM, Lubitz W (1996) Classification and identification of bacteria: current approaches to an old problem. Overview of methods used in bacterial systematics. J Biotechnol 47:3-38

Chen YP, Rekha PD, Arun AB, Shen FT, Lai WA, Young CC (2006) Phosphate solubilizing bacteria from subtropical soil and their tricalcium phosphate solubilizing abilities. Appl Soil Ecol 34:33-41

Chin-A-Woeng TFC, De Priester W, Van Der Bij AJ, Lugtenberg BJJ (1997) Description of the colonization of a gnotobiotic tomato rhizosphere by Pseudomonas fluorescens biocontrol strain WCS365, using scanning electron microscopy. Mol Plant Microbe Interact 10:79-86

De Bruijn I, De Kock MJD, Yang M, De Waard P, Van Beek TA, Raaijmakers JM (2007) Genome-based discovery, structure prediction and functional analysis of cyclic lipopeptide antibiotics in Pseudomonas species. Mol Microbiol 63: 417-428

Doyle JJ, Doyle JL (1990) Isolation of plant DNA from fresh tissue. Focus 12:13-15

Hanna AL, Youssef HH, Amer WM, Monib M, Fayez M, Hegazi NA (2012) Diversity of bacteria nesting the plant cover of north Sinai deserts, Egypt. J Adv Res. https://doi.org/10.1016/j.jare.2011.11.003

Hayat R, Ahmed I, Peak J, Ehsan M, labal M, Chang YH (2013) A moderately boron tolerant candidates novel soil bacterium Lysinibacillus pakistanensis sp. nov. cand., isolated from soybean (Glycine max L) rhizosphere. Pak J Bot 45: $41-50$

Janda JM, Abbott SL (2007) 16S rRNA Gene sequencing for bacterial identification in the diagnostic laboratory: pluses, perils, and pitfalls. J Clin Microbiol 45:2761-2764

Karagöz K, Ates F, Karagöz H, Kotan R, Çakmakç R (2012) Characterization of plant growth-promoting traits of bacteria isolated from the rhizosphere of grapevine grown in alkaline and acidic soils. Eur J Soil Biol:144-150

Koskey G, Mburu SW, Kimiti JM, Ombori O, Maingi JM, Njeru EM (2018) Genetic characterization and diversity of rhizobium isolated from root nodules of mid-altitude climbing bean (Phaseolus vulgaris L.) varieties. Front Microbiol 15(9):968. https://doi.org/10.3389/fmicb.2018.00968

Kumar A, Kumar A, Devi S, Pati S, Paya C, Negi S (2012) Isolation, screening and characterization of bacteria from rhizospheric soils for different plant growth promotion (PGP) activities: an in vitro study recent research in science and technology. 4(1):01-05

Lin DX, Man CX, Wang ET, Chen WX (2007) Diverse rhizobia that modulate two species of Kummerowia in China. Arch Microbiol 188:495-507

Lugtenberg BJ, Dekkers L, Bloemberg GV (2001) Molecular determinants of rhizosphere colonization by Pseudomonas. Annu Rev Phytopathol 39: 461-490

Mignard S, Flandrois JP (2006) 16 S rRNA sequencing in routine bacterial identification: a 30-month experiment. J Microbiol Methods 67:574-581

MSTATC (1990) A microcomputer program for the design. Management and analysis of agronomic research experiments. Michigan State University, East Lansing

Naseby DC, Way JA, Bainton NJ, Lynch JM (2001) Biocontrol of Pythium in the pea rhizosphere by antifungal metabolite producing and non-producing Pseudomonas strains. J Appl Microbiol 90:421-429

Rosselló-Mora R, Amann R (2001) The species concept for prokaryotes. FEMS Microbial Rev 25:39-67
Simons M, Van Der Bij AJ, Brand I, De Weger LA, Wijffelman CA, Lugtenberg BJJ (1996) Gnotobiotic system for studying rhizosphere colonization by plant growth-promoting Pseudomonas bacteria. Mol Plant-Microbe Interact 9:600-607

Vessey JK, Cheminigwa GN (2006) The genetic diversity of Rhizobium leguminosarum bv. viciae in cultivated soils of the eastern Canadian prairie. Soil Biol Biochem 38:153-163

\section{Publisher's Note}

Springer Nature remains neutral with regard to jurisdictional claims in published maps and institutional affiliations.

\section{Submit your manuscript to a SpringerOpen ${ }^{\circ}$ journal and benefit from:}

- Convenient online submission

- Rigorous peer review

- Open access: articles freely available online

High visibility within the field

- Retaining the copyright to your article

Submit your next manuscript at $\boldsymbol{\nabla}$ springeropen.com 